https://helda.helsinki.fi

\title{
Analytic Aesthetics
}

\section{Mikkonen, Jukka}

Palgrave Macmillan

2018

Mikkonen , J 2018 , Analytic Aesthetics . in B Stocker \& M Mack (eds), The Palgrave

Handbook of Philosophy and Literature . Palgrave Macmillan , Lontoo , pp. 295-314 . https://doi.org/10.1057/978-1-1

http://hdl.handle.net/10138/323964

https://doi.org/10.1057/978-1-137-54794-1_14

acceptedVersion

Downloaded from Helda, University of Helsinki institutional repository.

This is an electronic reprint of the original article.

This reprint may differ from the original in pagination and typographic detail.

Please cite the original version. 
Analytic Aesthetics

Jukka Mikkonen

\begin{abstract}
'We ask, "What is the meaning of this piece of music?" without stopping to ask ourselves what it is that we are asking, precisely what sense of "meaning" is being used here, or what it means for a work of art to have meaning. We assert that art reveals reality, or expresses truth, without inquiring into the precise meanings of crucial words like "reality," "truth," "expression," which are so constantly employed in discussions of this kind' (Hospers 1946, v).
\end{abstract}

This passage from John Hospers's Meaning and Truth in the Arts (1946) illustrates well the aim of the early analytic enterprise in aesthetics: the investigation of key concepts in a discourse. While 'analytic philosophers' are today critical about both the demarcation between analytic and Continental philosophy and attempts to define analytic philosophy, something can be said of the characteristics of the analytic enterprise in aesthetics. Typical for the analytic approach are, according to its self-acknowledged proponents, the application of formal logic, conceptual analysis, and rational argument; the focus on detail and distinctions and the orientation to narrowly demarcated problems; the emphasis on objectivity and a view of philosophical problems as timeless; and a respect for clarity and a preference for clear prose (Lamarque \& Olsen 2004a, 2; Currie et al. 2014, 5). Analytic philosophers of literature have been interested in the nature of general concepts, such as 'literature', 'fiction', 'narrative' and 'meaning', on the one hand, and the practice of literature, on the other hand. 
1. The analytic approach

Philosophers' work around philosophy and literature may be roughly divided into two groups: 'philosophy and literature' and 'philosophy of literature'. The former mainly explores the philosophical aspects of literary works (or the literary aspects of philosophical works) and deals with actual works, whereas the latter consists of systematic exploration of theoretical issues related to literature. In addition, analytic philosophers' have used to illustrate their theories with examples drawn from literature, philosophers of language examining fictional entities such as Hamlet and moral philosophers illuminating ethical problems with literary scenarios; these approaches that make use of literary works do not fall within either of the groups mentioned. Analytic aestheticians are mainly working on the philosophy of literature.

There are, crudely stated, three popular views of the aims of the analytic mission among contemporary aestheticians. These views, which need not be mutually exclusive, are: (i) a philosophy of criticism, (ii) a philosophy of empirical study of art, and (iii) a philosophy of art.

i. The early analytic aestheticians of the 1950s conceived their discipline as 'metacriticism' or the philosophy of criticism. Their aim was to discover the fundamental concepts and general principles of art criticism by looking carefully at the work of professional critics. This conception of the discipline was clearly manifested in Monroe C. Beardsley's work Aesthetics (1958), which was subtitled 'Problems in the Philosophy of Criticism'. Today, many analytic philosophers of art think that the scope of aesthetics is much broader than the analysis of concepts. Philosophers are interested in issues, such as creativity and restoration: also, 
questions in metaphysics and the philosophy of mind have a central role in contemporary study (see Stock \& Thomson-Jones 2008, xii). Some think that descriptive or normative metacriticism is not even possible any more, for criticism has become so diverse an object that a coherent view of its methods cannot be given-moreover, the rise of a new critical paradigm would make the philosophical descriptions of critical principles obsolete (Lamarque 2009, 7). Others defend metacriticism as a part of the analytic approach. Noël Carroll claims in On Criticism 'that the time has come to rejuvenate [metacriticism], since there is probably more art criticism being produced and consumed now than ever before in the history of the world' (Carroll 2009, 1). The metacritical conception is also manifest in many contemporary analytic aestheticians' work in which critical readings, the interpretations of the experts of art, are cited as evidence supporting the philosopher's theoretical thesis.

ii. Interest in the 'psychology of art' has been strong in analytic aesthetics, which is no wonder, as analytic philosophers are often (but not always) sympathic to natural scientific approaches. Along the rise of neuroscience and cognitive science, a growing number of aestheticians have taken an interest to the findings of the sciences of the mind. If neuroscience helps us to understand information processing in general, could it not also illuminate our engagement with works of art? Some philosophers have taken scientific studies to settle ageold philosophical debates for good, but Kathleen Stock $(2014,205)$ remarks perceptively that 'given philosophers' tendencies to cautious critical analysis, the use of such evidence is not always inspected as scrupulously as it could be'. Gregory Currie believes that aestheticians would learn much if they turned their attention to empirical disciplines, such as branches of psychology, linguistics and economic and sociological studies of art consumption: yet, he thinks that empirical research is not much worth without careful philosophical reflection of the traditional sort, and he sees the task of philosophy in formulating theoretical models to 
strengthen the empirical study (Currie 2013, 435-436). Currie and his colleagues $(2014,12)$ argue that '[w]hilst phenomenological and conceptual analysis may tell us much about what we think we are doing [in experiencing artworks], even aesthetic experts may be mistaken about what they are actually doing. And this, at least in principle, may be the object of scientific investigation'.

iii. Peter Lamarque and Stein Haugom Olsen propose that philosophy of literature is best understood as literary aesthetics or the philosophy of the phenomenon of literature. As Lamarque $(2009,8)$ sees it, "the "institution" of literature investigated by the philosopher concerns ... fundamental structures, those that, in Kantian terminology, "make possible" any relevant interations between participants in a practice'. In this view, the philosopher is after "the logical foundations of the "practice" of literature, rather as the philosopher of law examines neither particular legal systems nor the history of law but the grounds on which any such system depends[.]' (ibid.). Moreover, Lamarque and Olsen (2004b, 201) emphasize that philosophy of literature ought to be aesthetics of literature and focus on the 'recognizably valuable but non-instrumental experience that has traditionally been referred to by the term "pleasure"'. Such an approach examines, for instance, the sort of values associated with literature.

\section{Definitions of Literature}

The word 'literature' is used to denote any body of writing, on the one hand, and artistically valuable texts, on the other hand. In the latter group are works of the imagination, such as novels, epic poems and plays. But not all works of imagination, such as genre fiction, are 
considered literature proper; in turn, some non-fictional works, such as works of history, travel stories, philosophical works, are seen to possess significant literary value. As aesthetics in general has been eager to find out what art is, literary aesthetics is keen to know what literature is in the aesthetic sense.

Aestheticians of today are extremely dubious about essentialist definitions that attempt to ground literature on some intrinsic quality, such as 'literariness', or some sort of psychological response to it in the audience. The consensus is that there are no necessary and sufficient conditions that would make a text literature. Noël Carroll $(1988,149)$ takes a 'historical or narrative approach' and claims that
'Art is a cultural practice that supplies its practitioners with strategies for identifying new objects as art. ... Confronted by a new object, a practitioner of the artworld considers whether it can be shown that the new work is a repetition, amplification or repudiation of the tradition.'

Likewise, Jerrold Levinson (2007, 28-29) states in his 'recursive' definition of art that 'an artwork ... is something that has been intended by someone for regard or treatment in some overall way that some earlier or preexisting artwork or artworks are or were correctly regarded or treated'. Robert Stecker $(1996,694)$, in turn, proposes a 'disjuctinctive' definition of literature:

'a work $w$ is a work of literature if and only if $w$ is produced in a linguistic medium, and, 
1. $w$ is a novel, short story, tale, drama, or poem, and the writer of $w$ intended that it possess aesthetic, cognitive or interpretation-centered value, and the work is written with sufficient technical skill for it to be possible to take that intention seriously, or 2. $w$ possesses aesthetic, cognitive or interpretation-centered value to a significant degree, or

3. $w$ falls under a predecessor concept to our concept of literature and was written while the predecessor concept held sway, or 4. $w$ belongs to the work of a great writer.'

In Lamarque and Olsen's $(1994,255-256)$ 'institutional' view, '[a] text is identified as a literary work by recognizing the author's intention that the text is produced and meant to be read within the framework of conventions defining the practice (constituting the institution) of literature'. Further, the aesthetic value of literature consists of mimesis and poiesis: humanly interesting content and the creative and imaginative aspect of treating that content (ibid., 261-266).

Of course, all these characterizations have been disputed. Perhaps there is only a 'literary' way of reading? Such a view has also been criticized for not being able to distinguish between works that possess literary value and works that are merely treated as literature (i.e. read with an emphasis on their rhetorical features, for instance).

3. Ontology and Epistemology of Literature 
In addition to the definition of literature, there has been a now somewhat declining interest in the ontology of literary works. How does a literary work exist? Analytic philosophers have provided subtle and nuanced ontological systems, of which two major strands are 'textualism' and 'contextualism'. Textualists maintain that a literary work is to be identified with the text of the work, or rather, the text-type. For Nelson Goodman $(1976,208)$, '[a] literary work ... is ... the text or script itself'. A problem arises when we have multiple versions of the text, such as manuscripts of Joyce's Ulysses. Morever, in a strict textualist view a literary work of art cannot survive translation, so a person who has read Notes from the Underground would not have read Dostoyevsky's work Записки из подполья.

Contextualism, in turn, maintains that a literary work is a text-type tied to its context of origin. A 'poem is not ... the brute text that it comprises but rather that text poetically projected in a specific context anchored to a particular person, time, and place' (Levinson 1996, 197). Because features of the art historical context of the work affect to its identity, textually identical texts that are produced in different historical contexts would constitute different works. Proponents of contextualism like to refer to Borges's playful short story 'Pierre Menard, Author of the Quixote' ('Pierre Menard, autor del Quijote', 1939), in which a fictional 20th-century French writer achieves to produce fragments that are verbally identical to Cervantes's Don Quixote but which are much richer in meaning, for they connotate things that Cervantes's 17th century text could not. But what all belongs to the 'historical context' of a work and how strict the requirements should be? Which properties of the work's spatiotemporal context are accidental and which properties essential to its identity? How much contexts constrain textual meanings and how much this ultimately affects the works? 
Part of the ontology of literature is the question how fictional characters, such as Emma Bovary, exist. Eliminativists like Nelson Goodman (1976/1968) and Kendall L. Walton (1990) attempt to get rid of apparent reference to fictional entities by paraphrasing them, whereas accommodativists, such as Nicholas Wolterstorff and Amie Thomasson (1999), think that fictional entities are nonexistent objects, possible objects, abstract entities, Platonic kinds or the like.

While the study on the semantics of fiction has been to a large extent carried out by metaphysicians, the ontology of 'fictional worlds' and the question of 'fictional truths' has united aestheticians with metaphysicians and philosophers of language. A literary works does not reveal its readers everything about the characters and the events, and readers have to make a great deal of interferences about the state of affairs in the world of the work. Readers supplement the narrator's reports on both personal grounds (e.g. spontaneous visual imaginings) and ways that are suggested by the work. Some indeterminacies are subject to interpretative debates, e.g. whether the ghosts the governess sees in Henry James's The Turn of the Screw (1898) are hallucinations or real. How do we determine what is true in a fiction? David Lewis's (1978) view of a fictional world as a set of possible worlds and fictional truth as a matter of counterfactual reasoning has been highly influential and disputed. Kendall Walton (1990) has scrutinized two competing principles that have been proposed to explain how we infer fictional truths. According to the 'Reality Principle' (RP), readers assume that the fictional world is as much like the real world as is compatible with the work's descriptions and make their inferences accordingly.

Conversely, the 'Mutual Belief Principle' (MBP) maintains that our inferences about the world of a fiction ought to follow the beliefs common in the artist's society. 
In a society in which earth is believed to be flat, adventurers near the 'edge' of the world are fictionally in danger of falling down; 'Our superior geographical knowledge need not ruin the excitement for us.' (ibid., 152) While the both principles turn out to be problematic in Walton's inspection, he thinks that 'MBP not only gives the artist better control over what is fictional; it also, in many cases, gives appreciators easier access to it' (ibid., 153).

There are great many disputes around these principles. What are the 'mutual beliefs' of a society — and what if the author is at odds with them? Lamarque $(1990,335)$ has criticized the realistic assumptions underlying many theories of fictional truth and their neglect for literary interpretation, such as Lewis's 'assumption that there are "facts" about the fictional worlds waiting to be discovered'. Of late, he has claimed that it is difficult to establish beliefs about fictional matters and that many fictional 'facts' turn out to be disputable (Lamarque 2016). The question of truth in fiction has received much attention in aesthetics; little has been written on the aesthetic value of epistemic ambiguity in literature.

\section{Fiction}

The definition of fictionality and the nature of our attitude toward the content of works of imaginative literature has greatly fascinated analytic philosophers. Today, most analytic aestheticians think that fiction is not to be defined in semantic terms (reference and truth), for works of fiction often accordingly refer to real people, places, and events, whereas nonfictional works may fail in their references (or truth) without becoming fiction. Rather, fictions invite a certain kind of response in the audience. In his Mimesis as Make-Believe (1990), Walton made popular the idea that engaging with a fiction means adopting a 'make- 
believe' attitude to the content of the work. Walton turned the attention to the social dimension of fiction and proposed that fictions are "works whose function is to serve as props in games of make-believe' (72).

The same year Gregory Currie, in his The Nature of Fiction, emphasized the role of the author's 'fictive intention' as a base for fictionality. In Currie's view, influenced by H. P. Grice's theory of meaning, the informal definition of fiction is as follows:

'I want you to make believe some proposition $P$; I utter a sentence that means $P$, intending that you shall recognize this is what the sentence means, and to recognize that I intend to produce a sentence that means $P$; and I intend you to infer from this that I intend you to make believe that $P$; and, finally, I intend that you shall, partly as a result of this recognition, come to make belive that $P . '($ Currie 1990, 31)

Currie thinks that the author's intention is crucial for us to distinguish between works that are fictions and works that are merely treated as fictions; this idea has become a commonplace in the paradigmatic 'fictive utterance' theories that followed from Currie's proposal.

But is there a particular state of mind associated with our engagement with a fiction? Currie (ibid., 21) notes that a newspaper article or a work of history can 'stimulate the imagination' the same way a fiction does. He proposes that the reading of fiction differs from the reading of non-fiction not because of the activity of the imagination but the attitude we adopt toward the content of the work: make-belief in fiction, belief in nonfiction. 
There has been a lively discussion on the nature and kinds of imagination in our engagement with fiction. Stacie Friend $(2008,151)$ argues that 'there is no interpretation of imagining or make-believe that designates a response distinctive to fiction as opposed to nonfiction'. She claims that

\begin{abstract}
'The class of works that invite make-believe or imagining is substantially broader than our ordinary notion of fiction. ... Vividly told non-fiction narratives invite us to imagine what it was like for people to live in different times and places, to undergo wonderful or horrible experiences, and so on.' (Friend 2012, 183)
\end{abstract}

Friend suggests that we should think of fiction as a genre. For her (ibid., 187), the distinction between fiction and non-fiction ought to pay attention to 'how the whole work is embedded in a larger context, and specifically in certain practices of reading, writing, criticizing, and so on'.

Derek Matravers also argues that we should not reserve imagination for fictions; he claims that we imagine fictional narratives not because of their fictionality but narrativity. In Matravers's view our engaging with a representation (narrative) is neutral between nonfiction and fiction and that imagination does not separate fiction from non-fiction:

'The experience of reading de Quincey's 'The Revolt of the Tartars' is the same whether we believe it is non-fictional, believe it is fictional, or (as is most likely) we are ignorant of whether it is non-fictional or fictional (in fact, it is a highly fictionalized account of actual events.)' (Matravers 2014, 78.) 
Matravers wants to replace the distinction between fiction and non-fiction with a distinction between 'representations' and 'confrontations': situations in which action is not possible (what is being represented to us is out of reach) and situations in which action is possible. $(2014,50,57)$.

Currie has also revised his view of imagination in our engagement with fiction. Drawing on a distinction between 'propositional' and 'perceptual' imagination and the idea of the intensity of imagining, he proposes that 'imaginings vary a good deal in their perceptual and emotional intensity' and that 'it is plausible to suppose that our judgments about the fictional status of a work depend partly on the intensity of the imaginings they provoke' (Currie 2014, 361).

Walton, in turn, has come to question his own definition of fiction, in which a proposition is fictional only in case there is a prescription that it is to be imagined: 'I have come to realize, belatedly, that this is only half right. Prescriptions to imagine are necessary but not sufficient for fictionality.' (Walton 2015, 17) Walton remarks that metarepresentation, such as stories within stories and pictures within pictures, are to be imagined but are not fictional (fictionally true) in the world of the work.

Of recent, analytic aestheticians have much explored the limits of imagining. There has been a sparkling discussion on 'imaginative resistence', our inability or unwillingness to imagine fictional propositions that clash with our moral attitudes, for instance. The phenomenon was problematized by Walton, who found it described by David Hume. Walton $(1994,29)$ remarks that ' $[\mathrm{m}]$ orally repugnant ideas may so distract or upset us that we are unable to appreciate whatever aesthetic value the work possesses' - and that we may be unwilling even to try. He asks that 'If the text includes the sentence "In killing her baby, Giselda did the right 
thing; after all, it was a girl" ... are readers obliged to accept it as fictional that, in doing what they did, Giselda or the elders behaved in morally proper ways?' (ibid., 37). Walton thinks that the difficulty is in our imagining such views justified or true.

Tamar Szabó Gendler proposes that imaginative resistance occurs because the problematic fictional propositions take a general form: 'we are unwilling to follow the author's lead because in trying to make that world fictional, she is providing us with a way of looking at this world which we prefer not to embrace.' (Gendler 2000, 79; emphasis in original; see also Gendler 2006, 160).

The study of fictionality is a healthy topic of research and future will show what direction the research will take. Perhaps advances in the philosophy of mind, for instance, will contribute to theories of imagination in aesthetics.

\section{Narrative}

The zeitgeisty concept of narrative has received, for instance, ontological, epistemological and aesthetic attention in the philosophy of literature. Yet, several analytic philosophers are annoyned by the buzz and sceptical to, say, ethical or epistemic views grounded on the concept of narrative or narrativity. Paisley Livingston, for one, claims that there are serious problems in views which link narrativity and the epistemic merits or dismerits of stories. Livingston $(2009,28)$ argues that narrative enthusiasts have not been able to show that the value of narratives would be based on their narrativity. 
A special issue in the debate on the value of narratives in explaining human action is the difference between real-life narratives, the stories we tell about ourselves and others, and literary narratives, such as novels. Peter Goldie $(2012,151)$ thinks that we have several 'fictionalizing tendencies', as we 'tend to structure our autobiographical narratives in a way that makes them dangerously close to fictional narratives, and in particular to fictional narratives of the kind one finds in literature'. Goldie however argues that we need narrative for various purposes, such as understanding emotional processes (e.g. grief). Also, he maintains that there is a surplus of meaning in narrative devices, such as dramatic irony and free indirect discourse.

Lamarque has criticized theories that seek to understand real lives with the help of literary narratives, asserting that literary narratives and our real-life narratives are radically different. He argues that the content of a literary work is 'perspectival' and essentially given from a particular point of view. According to him, this 'opacity', as he also calls it, 'runs deep in narrative representation: tone, irony, humour, connotation, allusion, narrative voice and other aspects of representation colour all narrative that aspires to literary status' (Lamarque 2014, 166). Moreover, he claims that to see fictional characters as ordinary people and their lives essentially like ours is to 'ignore all essentially literary qualities and reduce literature to character and plot at the same level of banality as found in the stories we tell of ourselves' (ibid., 68).

In the analytic tradition, the discussion on narrative also boils down to so-called fundamental questions: what exactly are narratives and what is the value of stories qua stories; how we can distinguish what is due to narrativity and what is due to temporality or causality in our explanations of human action, and so on. 
6. Meaning and interpretation

Analytic philosophy, which many identified as linguistic philosophy at a time, has been obsessed with truth and meaning. Against this background, it is no wonder how keen analytic aestheticians have been exploring 'meaning' in the arts. Analytic philosophers of art have studied, for example, the idea of a 'right' interpretation and the compatibility of different critical interpretations (see Krausz ed., 2002). Reasoning and justification in art interpretation and the truth-conditions of interpretative judgements have been historically focal topics. Barrells of ink have been spilled on the question of the author's intention in art interpretation, a debate that begun with William K. Wimsatt and Monroe C. Beardsley's article 'The Intentional Fallacy' (1946). Today, there are roughly three parties in the intention debate: 'anti-intentionalists', 'actual intentionalists', and 'hypothetical intentionalists'.

Anti-intentionalist or 'value maximization' theories claim that the author's semantic intentions - what she meant by her use of words - are irrelevant in interpretation. Alan Goldman, for one, considers the aim of art interpretation to enhance the aesthetic experience of artworks. Goldman $(1990,207)$ states that 'an interpretive explanation is best when it successfully aims to maximize the artistic value of the interpreted work'. The view allows that there can be equally acceptable but incompatible interpretations; yet, 'not all interpretations are equally acceptable or acceptable at all', for an interpretation has to be consistent with 'elements and properties' of the work and its context (ibid., 208, 206). Further, Goldman suspects that 
'artists' reticence about their intentions has much more to do with leaving room for unintended valuable properties in their works leading to better aesthetic experiences in audiences and positive evaluations by critics than it has to do with inabilitites to express themselves in words' (Goldman 2013, 33).

In turn, actual intentionalists are after the intentions of the historical, flesh-and-blood author. 'Absolute' intentionalism, which does not have much support today, maintained that the meaning of a work of fiction is the meaning the author intended in composing it. The problem of the view is that an author could make her work mean anything simply by deciding so. For 'moderate' intentionalists of today, such as Noël Carroll, Gary Iseminger, Robert Stecker, and Paisley Livingston, a correct interpretation of a work of literature is the meaning of the text compatible with the actual author's intention. For instance, in Carroll's 'modest' actual intentionalism the meaning of a work is constrained by the textual meaning, or word sequence meaning, and the best information about the author's intended meaning, where available. Best information, in turn, consists of evidence such as the art-historical context of the work, common beliefs of the contemporary audience, the author's public biography, her oeuvre, and the like (Carroll 2001, 197-198 \& 200-201; Carroll 2002, 321, 323, 326 \& 328).

Hypothetical intentionalism considers the meaning of a literary work an assumption of either the actual author's or a 'hypothetical' or 'postulated' author's intended meaning by referring to the beliefs and expectations of the author's 'intended', 'ideal' or 'appropriate' audience. Jerrold Levinson $(2010,150)$ writes that

'it is false that [François Ozon's film Swimming Pool (2004)] means only what it was intended to mean by its maker, even where it can somehow be seen as meaning what it 
was intended to mean. The film should rather be taken to mean, ambiguously, many of the other options ... which are reasonably attributed to the filmmaker on both epistemic and aesthetic grounds. The film is a much richer, more satisfying, work of art when so viewed.'

Alexander Nehamas $(2002,101)$ argues in his version of hypothetical intentionalism that while a literary work is interpreted and understood as its author's production, its author is not identical with the historical author. Instead, Nehamas argues, the author of a literary work is 'postulated as the agent whose actions account for the text's features; he is a character, a hypothesis which is accepted provisionally, guides interpretation, and is in turn modified in its light' (Nehamas 1981, 145).

Participants of the debate have been happy to point out problems in their opponents' models. Value maximization theories, for example, are said to distort the work's nature: Carroll states that Heinrich Anacker's anti-Semitic poems are rendered aesthetically more satisfying by regarding them as ironic, even though there are strong reasons to read them as sincere poems, as intended by Anacker. Maximizing their aesthetic value would be, however, dismissing their 'conversational' function. (Carroll 1992, 122-123 \& 178.) The critique of actual intentionalism, in turn, has problematized the realization of intentions: Saam Trivedi (2001, 196-198) claims that we cannot find out whether the author's actual intentions have been successfully realized in an artwork, because we cannot compare the intentions with some independent work-meaning and see if the two fit. Hypothetical intentionalism is accused for that it will ultimately collapse to actual intentionalism or that it cannot be distinguished from value maximization theory (for recent criticism, see Stecker and Davies 2010). 
Analytical theories of interpretation have drawn on the philosophy of language and applied concepts such as 'speech acts' and 'conversation' to literature. One topic of dispute has been whether literary works could be seen as utterances. Carroll (1992) and Stecker (2006) suggest that because of their nature as linguistic products of intentional human action, literary works are utterances similar to those used in everyday discourse. Conversely, Lamarque and Olsen claim that 'the importation of philosophy of language into the philosophy of literature has had badly distorting effects' $(2004 b, 204)$. They think that complete literary works do not possess a 'meaning' — which is something that can be stated. Moreover, they propose that literary interpretation focuses on stages beyond verbal understanding, namely, thematic investigation and aesthetic appreciation.

Some pluralistic models have been proposed: Perhaps there could be several legitimate interpretative approaches to works of literature, the intentionalist/conversational approach being one of these? Perhaps a single text could embody two works, say, a philosophical and a literary work, and these were to be interpreted accordingly? (see Davies 1995, 8-10; Gracia 2001, 52-56).

Debates on meaning and intention in the arts are peculiar. On the one hand, it would certainly be silly to narrow literary interpretation to a search for an authorial intention; on the other hand, the communicative dimension of art and issues such as a historical author's unintended racism and its relation to the 'meaning' of the work are surely worth exploring.

7. Literature and cognition 
The 'cognitivist' view that artworks, and literary works in particular, could provide their audiences significant knowledge and insight on worldly matters has been a perennial issue in aesthetics and one of the key topics in the analytic tradition. In addition to historical and geographical knowledge, literature is seen to provide knowledge of concepts (Gibson 2007), modal knowledge or knowledge of possibilities (Stokes 2006), or knowledge of emotions (Nussbaum 1990), to mention some. (Although analytic aestheticians speak of the cognitive value of literature, the investigation has been focused on the epistemic function of literature, which, again, is easy to understand calling in mind the history of analytic philosophy.)

Cognitivists claim that literary works may communicate their readers propositional knowledge (knowledge-that) and/or non-propositional knowledge (knowledge-how or knowledge-what-it-is-like). The traditional cognitivist position maintains that literary works could provide readers propositional knowledge by making assertions or implications or by advancing hypotheses (for some recent views, see e.g. Currie and Ichino 2016; Pettersson 2000; Kivy 1997a, 1997b). Traditional is also the thought that literary fictions could function akin to scientific thought-experiments (see e.g. Swirski 2007). In turn, the non-propositional camp commonly proposes that literary works could offer their readers knowledge of what it is like to be a in a certain situation (Nussbaum 1990, Gaut 2007), typically highlighting empathic identification with the reader and a character. So-called 'neo-cognitivist theories' often build on this non-propositional view, yet maintaining that literary works do not provide readers new knowledge but 'deepen' or 'clarify' or 'enhance' or 'enrich' readers' existing knowledge (Carroll 1998a; Graham 2000; Gibson 2007). In addition, neo-cognitivists usually see literary works capable of training readers' cognitive skills: literary works may, for instance, challenge the readers assumptions or her standard ways of thinking (Elgin 1993, John 1998). 
But 'anti-cognitivism' has also had a wide support. Anti-cognitivists insist that literary works do not furnish their readers with new knowledge, at least that of a traditional, propositional kind, and that the works do not therefore have cognitive value proper. Anti-cognitivists argue that if we understand the knowledge that literature affords in the traditional sense of the term, we make literary works subordinate to fact-stating discourse, and the cognitivist's task would be to explain how literature can convey knowledge, even though it is not assertive; the cognitivist ought to explain the distinctive cognitive value of literature, but so far her appeals to non-standard forms of knowledge are 'mere' metaphors with little explanatory value. Moreover, anti-cognitivists claim that literature's contributions to knowledge are trivial at best, or that the 'points' which literary works make are inarticulate or not agreeable among readers.

If literary works could change a reader's beliefs, would these changes inevitably be for good? Little has been said of the effects which literary works actually have on their readers. Partly inspired by the rise of empirical studies on the cognitive gains of literature, philosophers have started to ponder how learning from fiction could be studied and what would count as a proof for the claims on the educative function of literature (see e.g. Currie 2013).

8. Literature and ethics

Literary works allow us to explore moral positions, and many philosophers have seen special value in this. Martha Nussbaum (1997) has famously defended the idea that literary works yield edifying lessons. The question is important in exploring the intrinsic and instrumental 
values of literature: Are the ethical insights of an artwork part of its literary value? On the other hand, do ethical 'flaws' like an evidently racistic representation lessen the aesthetic value of an artwork?

Carroll's (1998b) 'moderate moralism' claims that in some cases a moral defect in a work of art can be an aesthetic defect and that in some cases a moral virtue can be an aesthetic virtue. Carroll argues that because works of art are incomplete and require the audience to fill them in or respond to them 'in a manner that facilitates the aim of the work', that response, including its emotional aspects, 'is part of the design of the artwork' $(1998,520)$. He claims that in American Psycho, for instance, fails aesthetically because 'the serial killings depicted in the novel are so graphically brutal that readers are not able morally to get past the gore in order to savour the parody' (Carroll 1996, 232).

Matthew Kieran, for his part, defends 'immoralism' which advances the view that 'a work's value as art can be enhanced in virtue of its immoral character'. Immoralism holds that 'imaginatively experiencing morally defective cognitive-affective responses and attitudes in ways that are morally problematic can deepen one's understanding and appreciation' (Kieran 2003, 72). Kieran reminds one that artworks' '[d]rawing on our moral judgements, reactions and assessments should not be conflated with arriving at and making the appropriate ones' (ibid., 60). For 'autonomists', such as James C. Anderson and Jeffrey T. Dean, art is a realm of its own. Autonomists claim that 'it is never the moral component of the criticism as such that diminishes or strengthens the value of an artwork qua artwork' (1998, 152; emphasis in original). 


\section{Literature and emotion}

Do we have to respond emotionally to works of literature in order to understand them properly? Many have argued that an emotional engagement with a fiction is a requirement for its proper understanding. It is also common to connect this view to a cogntivist position and claim that an empathic identification with a character gives us experiential knowledge or knowledge of emotions. Susan Feagin (1996, 242-255) has argued that affective responses to a literary work is a central part of appreciating it and, further, that a work's capacity to provide such responses is part of its literary value. For her, fictions expand the reader's 'affective flexibility'. Jenefer Robinson (2005, 110-111) claims that the reader's emotional responses toward fictional characters are themselves ways of understanding the characters and the situations in which they are. Berys Gaut argues that emotional responses to fictions may enlarge the reader's moral understanding:

'One way to learn morally is by seeing a person's situation as relevantly like another's to whom we know how to respond, and this can make the moral learning involved in our response to art both non-banal and aesthetically relevant. For instance, Tolstoy gives us a portrait of Anna Karenina that has psychological reality and depth, and Anna is presented in such a way that we are encouraged to view her sympathetically, rather than as a heartless woman who abandons a loyal husband. If one comes to learn morally from this artistic achievement, then one acquires the ability to see a real woman caught in a similar situation as an Anna Karenina.' (Gaut 2007, 173.)

These positions are accused of being too straightforward and unsophisticated literary responses (Posner 1997). Also, it has been argued that emotions felt in literary experience are 
relative to the reader and the genre of the work, and that the absense of such personal reactions in professional critcism shows that they are not an integral part of literary response (Lamarque 2009).

In addition to the relevance of emotions in interpretation, analytic philosophers have debated on the ontological status of our emotions in literary experience. Colin Radford (1975) started an immense debate on the 'paradox of fiction'. Radford asks how can we be moved by what we know does not exist? He considers such emotions genuine but largely irrational. Walton $(1978,13)$ suggests that we only 'make-believedly' pity Anna; what we feel is a mere quasiemotion. Lamarque $(1981,293)$ argues that our emotions are genuine as they are toward intentional objects (mental representations).

In turn, the 'paradox of tragedy' deals with our urge to engage with displeasing representations. How is it that we appreciate and gain pleasure from artworks that seem to offer us distressing experiences? In a characteristically analytic manner, Aaron Smuts (2009) has typologized the historical and contemporary discussion on the matter into six positions: (i) 'conversion theory' maintains that the overall experience of painful works of art is (retrospectively) pleasurable; (ii) 'control theories' hold that we can overcome the pain as we have the ability to stop the experience at our will; (iii) 'compenstation theories' state that we gain compensation (e.g. aesthetic pleasure) for our painful reactions; (iv) 'meta-response theories' assert that we are glad to see that, say, we feel pity at the suffering of others; (v) 'catharsis' theory claims that un unpleasant experience purifies - that is, immunizes or refines or expels - the emotions (pity, fear); and (vi) 'rich experence theories' argue that also painful experiences may be valuable and motivating. 


\section{Endword}

There has been relatively little productive intellectual exchange between analytic philosophers of literature and literary scholars, partly because literary criticism has in the recent decades been drawing on continental philosophy and partly because of the divergence of analytic philosophical and critical interests. Analytic philosophers like to scrutinize general concepts and put aside historical, political, and social issues that are important in critical approaches to actual works. Indeed, analytic philosophers' interest in the precise meanings of crucial words is so strong that sometimes they go so far as to invent their literary examples-something that literary critics might find disturbing. Then again, rigorous conceptual investigation may have problems in finding suitable examples from the actual practice. Analytic philosophers need to turn every conceptual stone, draw all the relevant distinctions and test their views with all the relevant counter-examples they can imagine. Of course, there has been fruitful interchange between analytic philosophers and literary scholars in the study of fictionality, for instance. But while one might think that the two disciplines could improve each other in various ways, one ought to keep in mind their different aims.

\section{References}

Anderson, James C. and Jeffrey T. Dean (1998), 'Moderate Autonomism', British Journal of Aesthetics, Vol. 38, No. 2, pp. 150-66.

Carroll, Noël (1988), ‘Art, Practice, and Narrative', The Monist, Vol. 71, No. 2, pp. 140-56. 
Carroll, Noël (1992), ‘Art, Intention, and Conversation', in Intention and Interpretation, ed. Gary Iseminger. Philadelphia: Temple University Press, pp. 97-131.

Carroll, Noël (1996), 'Moderate Moralism', British Journal of Aesthetics, Vol. 36, No. 3, pp. $223-38$.

Carroll, Noël (1998a), ‘Art, Narrative, and Moral Understanding', in Aesthetics and Ethics: Essays at the Intersection, ed. Jerrold Levinson. Cambridge: Cambridge University Press, pp. $126-60$.

Carroll, Noël (1998b), 'Moderate Moralism versus Moderate Autonomism', British Journal of Aesthetics, Vol. 38, No. 4, pp. 419-24.

Carroll, Noël (2001), 'Interpretation and Intention: The Debate between Hypothetical and Actual Intentionalism', in Beyond Aesthetics: Philosophical Essays. Cambridge: Cambridge University Press, pp. 197-213.

Carroll, Noël (2002), 'Andy Kaufman and the Philosophy of Interpretation', in Is There a Single Right Interpretation? ed. Michael Krausz. University Park: Pennsylvania State University Press, pp. 319-44.

Carroll, Noël (2009), On Criticism. New York: Routledge.

Currie, Gregory (1990), The Nature of Fiction. Cambridge: Cambridge University Press.

Currie, Gregory (2013), 'On Getting Out of the Armchair to Do Aesthetics', in Philosophical Methodology: The Armchair or the Laboratory? ed. Matthew C. Haug. London: Routledge, pp. 435-50.

Currie, Gregory and Anna Ichino (2016), 'Truth and Trust in Fiction'. Forthcoming in Art and the Nature of Belief, eds. Helen Bradley, Paul Noordhof and Ema Sullivan-Bissett

Currie, Greg, Matthew Kieran, Aaron Meskin \& Jon Robson (2014), 'Introduction', in Aesthetics \& the Sciences of Mind, ed. Greg Currie et al. Oxford: Oxford University Press, pp. 1-7. 
Davies, Stephen (1995), 'Relativism in Interpretation', Journal of Aesthetics and Art Criticism, Vol. 53, No. 1, pp. 8-13.

Davies, Stephen (2015), 'Defining Art and Artworlds', Journal of Aesthetics and Art Criticism, Vol. 73, No. 4, pp. 375-84.

Eaton, A. W. (2012), 'Robust Immoralism', Journal of Aesthetics and Art Criticism, Vol. 70, No. 3, pp. 281-92.

Elgin, Catherine Z. (1993/1991), 'Understanding: Art and Science', Synthese, Vol. 95, pp. $13-28$.

Feagin, Susan (1996), Reading with Feeling: The Aesthetics of Appreciation. Ithaca: Cornell University Press.

Friend, Stacie (2008), 'Imagining Fact and Fiction', in New Waves in Aesthetics, eds. Kathleen Stock and Katherine Thomson-Jones. Basingstoke: Palgrave Macmillan, pp. 150-69.

Friend, Stacie (2012), 'Fiction as a Genre', Proceedings of the Aristotelian Society, Vol. 112, No. 2, pp. 179-209.

Gaut, Berys (2007), Art, Emotion and Ethics. Oxford: Oxford University Press.

Gendler, Tamar Szabó (2000), 'The Puzzle of Imaginative Resistance', Journal of Philosophy, Vol. 97, No. 2, pp. 55-81.

Gendler, Tamar Szabó (2006), 'Imaginative Resistance Revisited', in The Architecture of Imagination: New Essays on Pretence, Possibility, and Fiction, ed. Shaun Nichols. Oxford: Oxford University Press, pp. 149-73.

Gibson, John (2007), Fiction and the Weave of Life. Oxford: Oxford University Press. Goldie, Peter (2012), The Mess Inside. Narrative, Emotion, \& the Mind. Oxford: Oxford University Press. 
Goldman, Alan (1990), 'Interpreting Art and Literature', The Journal of Aesthetics and Art Criticism, Vol. 48, No. 3, pp. 205-14.

Goldman, Alan (2013), Philosophy and the Novel. Oxford: Oxford University Press.

Goodman, Nelson (1976/1968), Languages of Art. Indianapolis: Hackett Publishing.

Gracia, Jorge J. E. (2001), ‘Borges's “Pierre Menard”: Philosophy or Literature?' Journal of Aesthetics and Art Criticism, Vol. 59, No. 1, pp. 45-57.

Graham, Gordon (2000), Philosophy of the Arts: An Introduction to Aesthetics. Second edition. London: Routledge.

Hospers, John (1946), Meaning and Truth in the Arts. Hamden: Archon Books.

John, Eileen (1998), 'Reading Fiction and Conceptual Knowledge: Philosophical Thought in Literary Context', The Journal of Aesthetics and Art Criticism, Vol. 56, No. 4, 331-48.

Kieran, Matthew (2003), 'Forbidden Knowledge: The Challenge of Immoralism', in Art and Morality, edited by José Luis Bermudez and Sebastian Gardner. London: Routledge, pp. $56-73$.

Kivy, Peter (1997a), 'On the Banality of Literary Truths', Philosophic Exchange, Vol. 28, pp. $17-27$.

Kivy, Peter (1997b), Philosophies of Arts: An Essay in Differences. Cambridge: Cambridge University Press.

Krausz, Michael, ed. (2002), Is There a Single Right Interpretation? University Park: Pennsylvania State University Press.

Lamarque, Peter (1981), 'How Can We Fear and Pity Fictions?’ British Journal of Aesthetics, Vol. 21, No. 4, pp. 291-304.

Lamarque, Peter (1990), 'Reasoning to What Is True in Fiction', Argumentation, Vol. 4, No. 3, pp. 333-46.

Lamarque, Peter (2009), Philosophy of Literature. Oxford: Blackwell. 
Lamarque, Peter (2014), The Opacity of Narrative. London: Rowman \& Littlefield International.

Lamarque, Peter (2016), 'Belief, Thought, and Literature'. Forthcoming in Art and the Nature of Belief. Edited by Helen Bradley, Ema Sullivan-Bissett and Paul Noordhof. Oxford: Oxford University Press.

Lamarque, Peter and Stein Haugom Olsen (2004a), 'General Introduction', in Aesthetics and the Philosophy of Art: The Analytic Tradition, eds. Peter Lamarque \& Stein Haugom Olsen. Malden: Blackwell, pp. 1-5.

Lamarque, Peter and Stein Haugom Olsen (2004b), 'The Philosophy of Literature: Pleasure Restored'. In Blackwell Guide to Aesthetics, ed. Peter Kivy. London: Blackwell, pp. 195214.

Lamarque, Peter and Stein Haugom Olsen (1994), Truth, Fiction, and Literature. A Philosophical Perspective. Oxford: Clarendon Press.

Levinson, Jerrold (1996), The Pleasures of Aesthetics: Philosophical Essays. Ithaca: Cornell University Press.

Levinson, Jerrold (2007), 'Artworks as Artifacts', in Creations of the Mind: Theories of Artifacts and Their Representation, eds. Eric Margolis and Stephen Laurence. Oxford University Press, pp. 74-82.

Levinson, Jerrold (2010), 'Defending Hypothetical Intentionalism', British Journal of Aesthetics, Vol. 50, No. 2, pp, 139-50.

Lewis, David (1978), 'Truth in Fiction', American Philosophical Quarterly, Vol. 15, No. 1, pp. 37-46.

Livingston, Paisley (2009), 'Narrativity and Knowledge', Journal of Aesthetics and Art Criticism, Vol. 67, No. 1, pp. 25-36.

Matravers, Derek (2014), Fiction and Narrative. Oxford: Oxford University Press. 
Nehamas, Alexander (1981), 'The Postulated Author: Critical Monism as a Regulative Ideal', Critical Inquiry, Vol. 8, No. 1, pp. 133-49.

Nehamas, Alexander (2002/1987), 'Writer, Text, Work, Author', in The Death and Resurrection of the Author? ed. William Irwin. Westport: Greenwood Press, pp. 95-116.

Nussbaum, Martha C. (1990), Love's Knowledge. Essays on Philosophy and Literature. New York: Oxford University Press.

Nussbaum, Martha C. (1997), Poetic Justice: The Literary Imagination and Public Life. Boston: Beacon Press.

Pettersson, Anders (2000), Verbal Art. A Philosophy of Literature and Literary Experience. Montreal: McGill-Queen's University Press.

Posner, Richard (1997), 'Against Ethical Criticism', Philosophy and Literature, Vol. 21, No. 1, pp. 1-27.

Radford, Colin (1975), 'How Can We Be Moved by the Fate of Anna Karenina?', Proceedings of the Aristotelian Society Supplementary Volume, Vol. 49, No. 1, pp. 67-93. Robinson, Jenefer (2005), Deeper than Reason: Emotion and Its Role in Literature, Music, and Art. Oxford: Oxford University Press.

Smuts, Aaron (2009), 'Art and Negative Affect', Philosophy Compass, Vol. 4, No. 1, pp. 3955.

Stecker, Robert (1996), 'What Is Literature?', Revue Internationale de Philosophie, Vol. 50, No. 198 , pp. 681-94.

Stecker, Robert (2006), 'Moderate Actual Intentionalism Defended', Journal of Aesthetics and Art Criticism, Vol. 64, No. 4, 429-38.

Stecker, Robert and Stephen Davies (2010), 'The Hypothetical Intentionalist's Dilemma: A Reply to Levinson', British Journal of Aesthetics, Vol. 50, No. 3, pp. 307-12. 
Stock, Kathleen (2011), 'Fictive Utterance and Imagining', Proceedings of the Aristotelian Society Supplementary Volume, Vol. 85, No. 1, pp. 145-61.

Stock, Kathleen (2014), 'Physiological Evidence and the Paradox of Fiction'. In Aesthetics and the Sciences of the Mind, ed. Greg Currie et al. Oxford: Oxford University Press, pp. 205-26.

Stock, Kathleen and Thomson-Jones (2008), 'Introduction', in New Waves in Aesthetics, eds. Kathleen Stock and Katherine Thomson-Jones. Houndmills: Palgrave-Macmillan, xi-xix.

Stokes, Dustin (2006), 'Art and Modal Knowledge', in Knowing Art: Essays in Aesthetics and Epistemology, eds. Matthew Kieran \& Dominic McIver Lopes. Dordrecht: Springer, pp. $67-81$

Swirski, Peter (2007), Of Literature and Knowledge: Explorations in Narrative Thought Experiments, Evolution and Game Theory. London: Routledge.

Thomasson, Amie L. (1999), Fiction and Metaphysics. Cambridge: Cambridge University Press.

Trivedi, Saam (2001), ‘An Epistemic Dilemma for Actual Intentionalism’, British Journal of Aesthetics, Vol. 41, No. 2, pp. 192-206.

Walton, Kendall L. (1978), 'Fearing Fictions', Journal of Philosophy, Vol. 75, No. 1, pp. 527.

Walton, Kendall L. (1990), Mimesis as Make-Believe: On the Foundations of the Representational Arts. Cambridge: Harvard University Press.

Walton, Kendall L. (1994), 'Morals in Fiction and Fictional Morality', Proceedings of the Aristotelian Society Supplementary Volume, Vol. 68, pp. 27-50.

Walton, Kendall L. (2015), 'Fictionality and Imagination-Mind the Gap', in Walton, In Other Shoes: Music, Metaphor, Empathy, Existence. Oxford: Oxford University Press, pp. $17-35$ 
Wimsatt, William K. and Monroe C. Beardsley (1987/1946), 'The Intentional Fallacy', in Philosophy Looks at The Arts, ed. Joseph Margolis. Philadelphia: Temple University Press, pp. $367-80$.

Wolterstorff, Nicholas (1980), Works and Worlds of Art. Oxford: Clarendon Press. 